\title{
Quality and Shelf Life of Fermented Lamb Meat Sausage with Rosemary Extract
}

\author{
Timothy J. Bowser ${ }^{1, *}$, Mwarumba Mwavita ${ }^{2}$, Ahmed Al-Sakini, William McGlynn ${ }^{3}$ and \\ Niels O. Maness ${ }^{3}$ \\ ${ }^{I}$ Department of Biosystems and Agricultural Engineering, Oklahoma State University, Stillwater, Oklahoma, USA \\ ${ }^{2}$ School of Educational Studies, Oklahoma State University, Stillwater, Oklahoma, USA \\ ${ }^{3}$ Department of Horticulture and Landscape Architecture, Stillwater, Oklahoma, USA
}

\begin{abstract}
Dry fermented lamb-meat sausages were manufactured with $70 \%$ lamb meat, $30 \%$ lamb fat and rosemary extract under a controlled fermentation and ripening process. The antioxidant effect of three rosemary extract concentrations $(0.015,0.030$ and $0.045 \%)$ on the oxidation stability, chemical composition, color parameter and sensory acceptability during ripening/drying and storage periods (1, 10, 25, 40 55, 70, 85 and 100 days) was studied. The fermentation process significantly ( $\mathrm{p}$ 0.05) reduced the moisture content, $\mathrm{pH}$ and water activity, while the components of protein, fat and ash increased during the processing and storage periods. Water activity, $\mathrm{pH}$ and moisture/protein ratio (MPR) were within the control criteria for shelf stable products. Rosemary extract (high total phenol concentration) was an efficient antioxidant, improving fermented lamb-meat sausage quality based on color and off-odor. Sensory analysis results, particularly appearance, juiciness, hardness and saltiness were not significantly different (p 0.05) in final products, while the sourness (acidity), color and off-odor mean values were significantly different ( $\mathrm{p} 0.05$ ).
\end{abstract}

Keywords: antioxidant, fermented, lamb, quality, rosemary, sausage.

\section{INTRODUCTION}

One of the most important fundamentals for the development of civilization was food preservation and storage. The transformation of raw materials to more-or-less stable foods by drying and fermentation was well known in many ancient cultures and used for different foods such as meat. Fermented sausage is one of the oldest known forms of processed meat products and is very popular in many areas around the world. Sausages were invented as a means of making the most of leftovers of meat and entrails. One of the most common fermented sausages is salami. Dry fermented sausages can be defined as meat products that are manufactured by selecting, chopping, and mincing lean and fat, with or without offal, adding condiments, spices, additives and starter culture (optional). The ingredients are stuffed into casings, ripened, cured, and in some cases smoked [1,2].

Dry fermented sausages are among the most difficult meat products to make. The manufacture of this type is economically important in many countries [3]. The time and energy requirements for the ripening process contribute a great deal to the total cost of fermented sausage manufacture; therefore accelerating this process would result in a reduction of the ripening time and an increased profit margin

*Address correspondence to this author at the Department of Biosystems and Agricultural Engineering, Oklahoma State University, Stillwater, Oklahoma, USA; Tel: ???????????????; Fax: ??????????????;

E-mail: bowser@okstate.edu and competitiveness of the final product [4]. Development of lipid oxidation in meat products during processing, distribution and storage adversely affects critical quality attributes such as flavor, color and nutritional value and has a major negative economic impact [5]. Oxidation of meat lipids is a complex process with dynamics that depend on numerous factors including: chemical composition of the meat, light and oxygen access, and storage temperature. The rate of the oxidation process is also affected by processing (e.g. cutting, chopping, comminuting, and mixing). Processing frequently limits the shelf-life of meat products [6].

The most efficient and practical way to prevent oxidative and color deterioration of meat products is to incorporate antioxidants into formulations [7]. Antioxidants are compounds or substances that can retard lipid oxidation and prolong product shelf life of meat products [8]. Hundreds of compounds, both natural and synthesized, have been reported to have antioxidant properties. In industrial processing, mainly synthetic antioxidants such as butylated hydroxylanisole (BHA) and butylated hydroxyltoluene (BHT) are used to prolong the storage stability of meat products [9].

Nowadays, there is increasing consumer awareness and health consciousness, which results in pressure to avoid the use of synthetic additives. This fact brings about the need for research regarding the use of natural additives or alternative methods to extend shelf life and /or improve food safety. 
Substances derived from the plant kingdom such as dried herbs and essential oils have been successfully used to reduce lipid oxidation in meat products [9]. Natural antioxidants extracted from herbs and spices exhibit various degrees of efficacy when used in different food applications [7]. Rosemary (Rosmarinus officinalis) is a natural spice that is used in everyday home cooking. It is also well-known as an antioxidant used in foods and cosmetics [10]. Rosemary has been reported to contain certain compounds including, rosmanol, rosmariquinone, rosmaridiphenol and carnosol, which may have antioxidant powers up to four times as effective as butylated hydroxyl anisole (BHA) and equal to butylated hydroxyl toluene (BHT) [11].

Formanek and others [12] found that color changes during storage were inhibited by the addition of rosemary extract in irradiated ground beef. Also Georgantelis and others [13] reported that rosemary extract protected the color of beef burgers during frozen storage. The objective of this study was to develop and evaluate a fermented lamb-meat sausage that was highly palatable, manufacturable, and shelfstable. The specific goals were:

1- Determine the effects of rosemary used as natural additives on the quality of lamb-meat sausages.

2- Evaluate the shelf life of fermented lamb-meat sausages formulated with different levels of rosemary as a natural antioxidant.

\section{MATERIALS AND METHODS}

Lamb-meat deboned from whole carcasses of adult animals (without sex distinction) used in this research, was provided by Robert M. Kerr Food \& Agriculture Products Center, Oklahoma State University, Stillwater, Oklahoma. Lamb lean meat was trimmed of visible fat. Also the lamb fat was trimmed from lamb ribs and loin. Lean and fat were cut into small cubes, packaged in polyethylene bags, frozen and stored at $-18{ }^{\circ} \mathrm{C}$. Before processing, the meat and fat were placed in a meat cooler at $4{ }^{\circ} \mathrm{C}$ to thaw. The manufacture of dry fermented lamb-meat sausage required three main steps: formulation, fermentation and ripening/drying.

Formulation was accomplished in four batches (treatments) of dry fermented lamb-meat sausages. Each batch contained $70 \%$ lamb-lean and $30 \%$ lamb-fat. Thawed lamb lean and fat at 0 to $2^{\circ} \mathrm{C}$ were minced using a grinder (BIRO model 548SS, Marblehead, Ohio) equipped with a 6 $\mathrm{mm}$ plate, then weighed. Other ingredients are listed in Table 1, and include starter culture (SafeProTM, Dry Bioprotective culture, Germany) and water (crushed ice). Rosemary extract powder (Sigma Aldrich Inc., Saint Louis, MO) was added at levels of $0.015,0.030$, and $0.045 \%(w / w)$ to treatments 2, 3 and 4, respectively. Ingredients for each treatment were blended separately a horizontal paddle mixer (model 100DA70, Leland Southwest, Fort Worth, TX) for three minutes. After blending, each treatment was minced a second time through the BIRO grinder equipped with a 3 mm plate.

Initial $\mathrm{pH}$ was measured using a meter (model 2212, Hanna Instruments Inc. RI). The sausage mixture was stuffed into $30 \mathrm{~mm}$ collagen casing (Mid-Western Inc., Wichita, KS)
Table 1. Ingredients added to lamb meat and fat during sausage formulation.

\begin{tabular}{|c|c|}
\hline Ingredient & Amount (\%, w/w) \\
\hline \hline Salt & 2.5 \\
\hline Sodium nitrite and nitrate & 0.30 \\
\hline Glucose & 0.05 \\
\hline Nutmeg & 0.15 \\
\hline White pepper & 0.15 \\
\hline Garlic & 0.15 \\
\hline Monosodium glutamate & 0.20 \\
\hline Starter culture & 0.03 \\
\hline Water (crushed ice) & 10.0 \\
\hline
\end{tabular}

using a stuffer (model VF 608, Handtmann. Lake Forest, IL). Approximately $12.5 \mathrm{~cm}$ length sticks were tied off, weighed, labeled, and hung in a ripening cabinet (model 1000, ALKAR-RapidPak, Inc., Lodi, WI) for fermentation and drying.

During the fermentation and drying processes, sausages were stored in the ripening cabinet according to the schedule shown in Table 2.

Table 2. Conditions maintained in the ripening cabinet to promote sausage fermentation.

\begin{tabular}{|c|c|c|}
\hline Time, $\mathbf{h}$ & Temp., $\mathbf{C}$ & Relative Humidity, $\%$ \\
\hline \hline 0 to 24 & 22 to 23 & 85 to 95 \\
\hline 24 to 48 & 18 to 20 & 80 to 90 \\
\hline 48 to 360 & 12 to 15 & 70 to 80 \\
\hline
\end{tabular}

Finally, the dry fermented lamb-meat sausage was removed from the ripening cabinet and placed into storage at $4 \mathrm{C}$ for up to 100 days. Fig. (1) shows Treatment 1 sausages after removal from the cabinet.

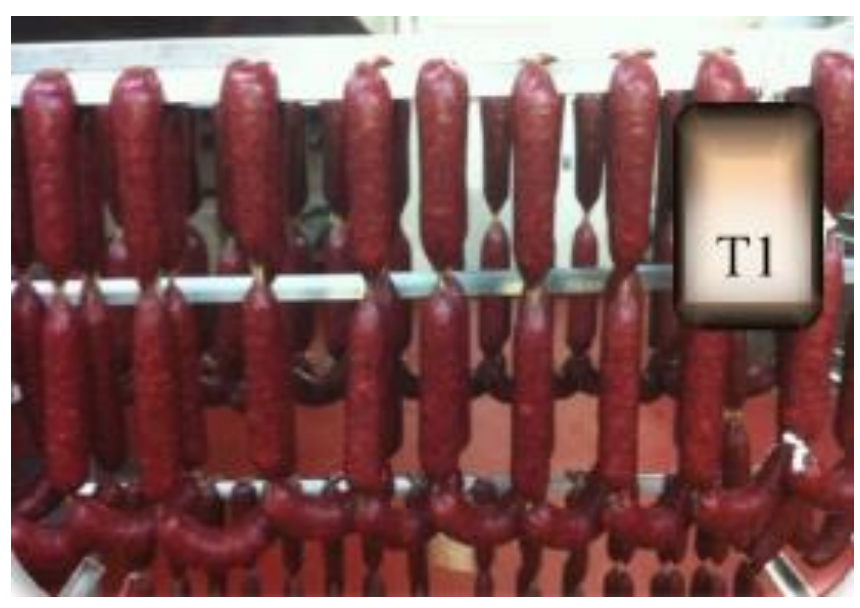

Fig. (1). Lamb-meat sausages of treatment 1 (control) after removal from the ripening cabinet at day 15 . 
Each treatment of lamb-meat sausage was analyzed for moisture, protein, and ash in triplicate. Fat was measured in duplicate according to AOAC [14] standards for proximate analysis. Samples were taken every two weeks, beginning on the first day of processing through day 100 .

The $\mathrm{pH}$ of sausage samples was measured in a homogenate prepared by blending $20 \mathrm{~g}$ of sausage with 80 $\mathrm{ml}$ of distilled water for 30 seconds (homogenizer model: PRO 250, Lab Depot, Inc., Dawsonville, GA). Water activity of sausage samples was measured using a meter (model CX2, Decagon Devices, Inc., Pullman, WA). Color measurements were made on a CR-3500d colorimeter (Minolta Chroma Meter Measuring Head, Osaka, Japan) with an $8 \mathrm{~mm}$ port size, illuminant D65, and a $10^{\circ}$ standard observer position, in a room with fluorescent lighting. Sausage samples were ground using a food chopper (model FG 1600 P, Black \& Decker, Miramar, FL) and sample color was measured three times. $L^{*}$ (lightness), $a^{*}$ (redness), $b^{*}$ (yellowness), $\mathrm{C}^{*}$ (Chroma) and $\mathrm{h}^{*}$ (hue) were obtained for each sample [3].

Samples of fermented lamb-meat sausages were evaluated by a volunteer sensory panel on three occasions (days 7, 60 and 90). Panelists were asked to evaluate 7 characteristics of the samples using a 10-point scale [15] that assessed: color, appearance, off-odor, acidity, saltiness, hardness and juiciness. Results were expressed as the predominant score given by panelists. Prior to analysis, panelists received training described by Martinez and others [16].

Sausage samples served to panelists were cooked in an oven (model XLT-3240TS2, BOFI, Inc., Wichita, KS) to an internal temperature of $70^{\circ} \mathrm{C}$. Samples were sliced to $1 \mathrm{~cm}$ thickness and presented on paper plates identified with threedigit random numbers. Panelists received samples of treatments at room temperature. Unsalted crackers and water were served for palate cleansing.

The experiments were designed with four treatments and three replications. Data obtained for chemical and physical

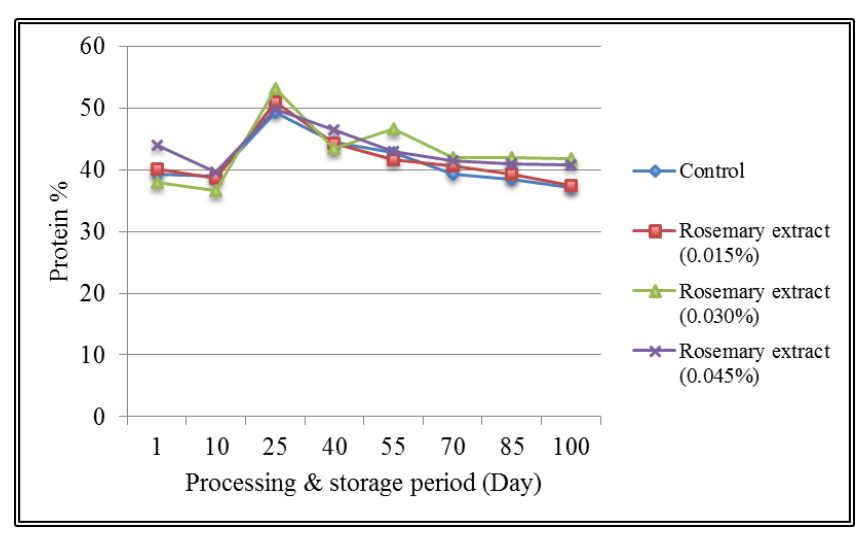

Fig. (2). Mean protein content values (\%) for dry fermented lambmeat sausage samples during processing and storage period.

properties (moisture, protein, ash, fat $\mathrm{pH}$, aw, and color) were statistically analyzed. Sensory data were analyzed using an analysis of variance (ANOVA), with the least square difference (LSD) method of the General Linear Model procedure (SPSS 19, SPSS Inc., UK).

\section{RESULTS}

Three replicates for each treatment were analyzed for moisture during the drying/ripening process as shown in Table 3. The mean moisture content declined during the drying/ripening process and the storage period for all batches, to $33.10,33.45,32.97$ and $34.41 \%$, respectively, at the end of $100^{\text {th }}$ day.

Three samples for each replicate were analyzed for protein content. The percent protein in dry fermented lambmeat sausage is important in relation to moisture content to obtain the desired moisture-protein ratio. Statistically significant differences in protein content between sausage samples $(p<0.05)$ were obtained at the end of the storage period (100 days). The mean values for protein content of dry fermented lamb-meat sausages are presented in Fig. (2). The fermentation process, drying and oxidation (oxidized

Table 3. Mean moisture values (\%) for dry fermented lamb-meat sausage during processing and storage.

\begin{tabular}{|c|c|c|c|c|}
\hline \multirow{2}{*}{ Time (day) } & \multicolumn{4}{|c|}{ Treatments } \\
\cline { 2 - 5 } & $\mathbf{1}$ & $\mathbf{2}$ & $\mathbf{3}$ \\
\cline { 2 - 5 } & \multicolumn{3}{|c|}{ Mean moisture, \% } \\
\hline \hline 1 & $54.83^{*}$ & $57.32^{*}$ & $55.92^{*}$ & $46.52^{*}$ \\
\hline 10 & $47.06^{*}$ & $47.31^{*}$ & $43.33^{*}$ & $34.45^{*}$ \\
\hline 25 & 33.90 & $32.84^{*}$ & 33.42 & 33.89 \\
\hline 40 & $34.06^{*}$ & 33.26 & 33.90 & $34.77 *$ \\
\hline 55 & $34.23^{*}$ & 33.34 & 34.75 & 34.03 \\
\hline 70 & $33.79 *$ & $33.41^{*}$ & 34.29 & 34.36 \\
\hline 100 & $34.85^{*}$ & $33.63^{*}$ & $32.97 *$ & $34.41^{*}$ \\
\hline
\end{tabular}

$*$ in the same column indicates that the mean difference is significant at the 0.05 level. 
protein) might affect the protein content amongst batches. Both [17] and [18] described a similar behavior in detection of protein oxidation.

Fat content of the sausage products affected sensory characteristics such as appearance, juiciness, color, hardness and palatability. Two samples for each replicate were analyzed for the fat content. Fig. (3) shows the mean values for fat percentage of the dry fermented lamb-meat sausage for all treatments. The total fat content increased $(\mathrm{p}<0.05)$ gradually throughout the ripening period as a result of water loss. The final fat contents were $31.99,31.81,33.55$ and $32.95 \%$ for all treatments, respectively.

Fig. (4) shows mean ash values for all dry fermented lamb-meat sausage samples. Three replicates for each treatment were analyzed for ash content during the study. The total ash content increased $(p<0.05)$ gradually throughout the ripening time as a result of water loss. The final ash contents were 8.63, 9.60, 9.59 and $9.85 \%$ respectively for the control and sausage samples with rosemary extract $(0.015,0.030$ and $0.45 \%)$. These results were in agreement with the results reported by [19] and [2].

Moisture/protein ratios (MPR) are commonly used to classify dried sausages and other meat products. MPR values are currently specified in FSIS labeling standards for shelf-

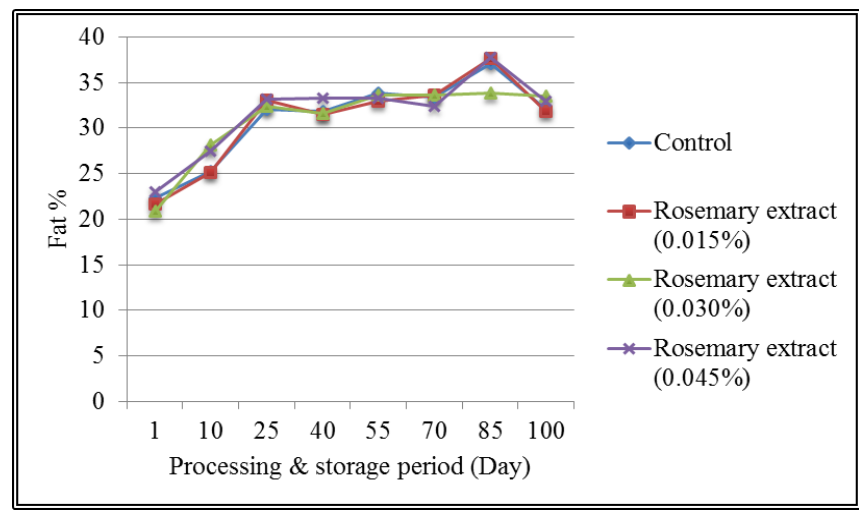

Fig. (3). Mean fat content values (\%) for dry fermented lamb-meat sausage samples during processing and storage.

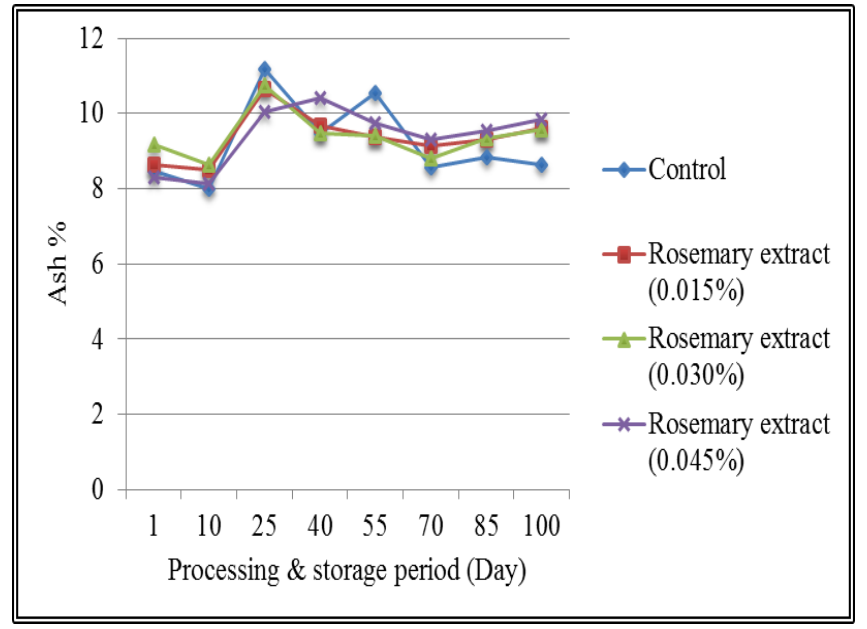

Fig. (4). Mean ash content values (\%) for dry fermented lamb-meat sausage samples during processing and storage. stable product. Shelf-stable dry sausages have an MPR of 1.9:1 or less to ensure a safe product [20]. In this study, dry fermented lamb-meat sausages had an MPR approximately of 1.2:1 for all products at the end of drying period. These results meet the labeling standards for shelf stable products regulated by FSIS.

Three replicates for each treatment were analyzed for water activity during processing and storage. The mean values for water activity are shown in Fig. (5). Water activity values were statistically different $(p<0.05)$ between the control and rosemary extract sausage samples. Water activity levels decreased from $0.96-0.95$ to $0.82-0.81$ during ripening and storage periods in all batches. Similar results were reported by [21] and [22] for low fat, dry fermented sausages. The water activity results of the current study are within the control criteria or the labeling standards for shelf stable products regulated by [20].

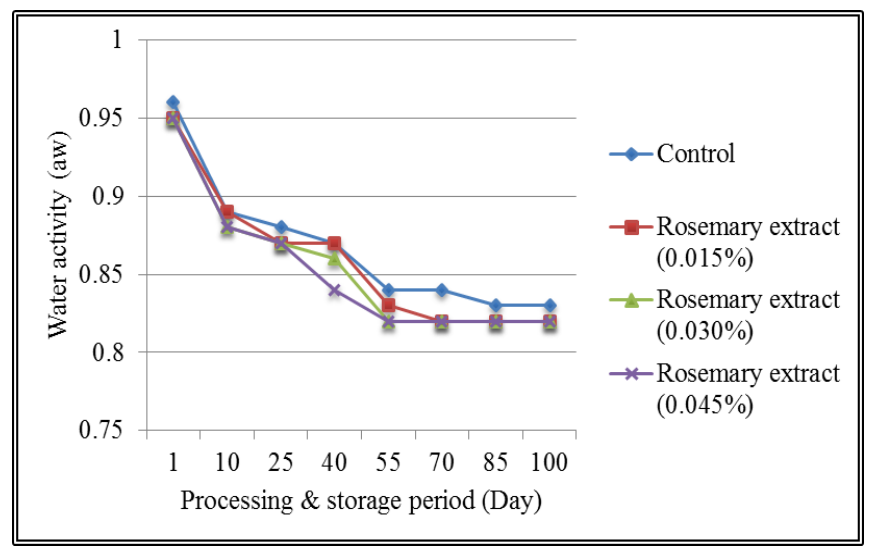

Fig. (5). Mean water activity values $\left(a_{w} \%\right)$ for dry fermented lambmeat sausage samples during processing and storage.

USDA FSIS [23] requires that shelf-stable sausages meet specific $\mathrm{pH}$ requirements (4.5 or lower for fermented type). Three replicates for each treatment were analyzed for $\mathrm{pH}$ during the processing and storage time of the study. The initial and fermented mean $\mathrm{pH}$ values of dry fermented lambmeat sausages are shown in Table (4). There were significant differences $(\mathrm{p}<0.01)$ in mean $\mathrm{pH}$ values of the products $(4.57,4.58,4.58$ and 4.56$)$ at day 100 , while the mean $\mathrm{pH}$ values at day 1 were 5.61, 5.59, 5.56 and 5.57 respectively. The fermentation process produced significant differences in $\mathrm{pH}$ amongst batches. Changes in $\mathrm{pH}$ were inversely proportional to the lactic acid bacterial count [24].

The color stability of fermented meat products is one of the most important quality criteria during both processing and storage periods [25]. Color measurements were taken on sausage samples. The following paragraphs describe the results for measurement of $a^{*}, b^{*}, L^{*}, C^{*}$, and $h^{*}$ values. For each value, three replicates were taken for each treatment. Color data was collected at days 1, 10, 25, 40, 55, 70, 85, and 100.

Redness values, $a^{*}$, are an indicator of red color stability in meat and meat products. The evaluation of a* values were considered to be important because they reflect the amount of red color and would be of interest to compare with visual evaluations of color [26]. The values of $a^{*}$ for samples, see 
Table 4. Mean pH values (\%) for dry fermented lamb-meat sausage during processing and storage.

\begin{tabular}{|c|c|c|c|c|}
\hline \multirow{3}{*}{ Time (day) } & \multicolumn{4}{|c|}{ Treatments } \\
\hline & 1 & 2 & 3 & 4 \\
\hline & \multicolumn{4}{|c|}{ Mean pH value } \\
\hline 1 & $5.61 *$ & $5.59 *$ & $5.56^{*}$ & $5.57 *$ \\
\hline 10 & $5.02 *$ & $5.02 *$ & $5.02 *$ & $5.01 *$ \\
\hline 25 & 4.62 & 4.62 & 4.61 & $4.63 *$ \\
\hline 40 & 4.60 & 4.62 & $4.63 *$ & 4.60 \\
\hline 55 & 4.61 & 4.61 & 4.59 & $4.60^{*}$ \\
\hline 70 & 4.60 & 4.61 & 4.60 & $4.59 *$ \\
\hline 85 & $4.57^{*}$ & $4.58 *$ & $4.58 *$ & $4.56^{*}$ \\
\hline 100 & $4.57^{*}$ & $4.58 *$ & $4.58^{*}$ & $4.56^{*}$ \\
\hline
\end{tabular}

* in the same column indicates that the mean difference is significant at the 0.05 level.

Fig. $(6)$, were higher $(\mathrm{p}<0.05)$ at the end of the storage period (day 100) compared to initial values. The trend in the changes of a* of samples was the same on the first 25 days $(p<0.05)$. The red color increased due to the incorporation of nitrite, nitrate addition and the ripening/drying process $(\mathrm{p}<$ 0.05 ). It is well-know that redness increases from the formation of nitrosylmyoglobin, which is formed under mildly acidic conditions by reaction of myoglobin with nitrites.

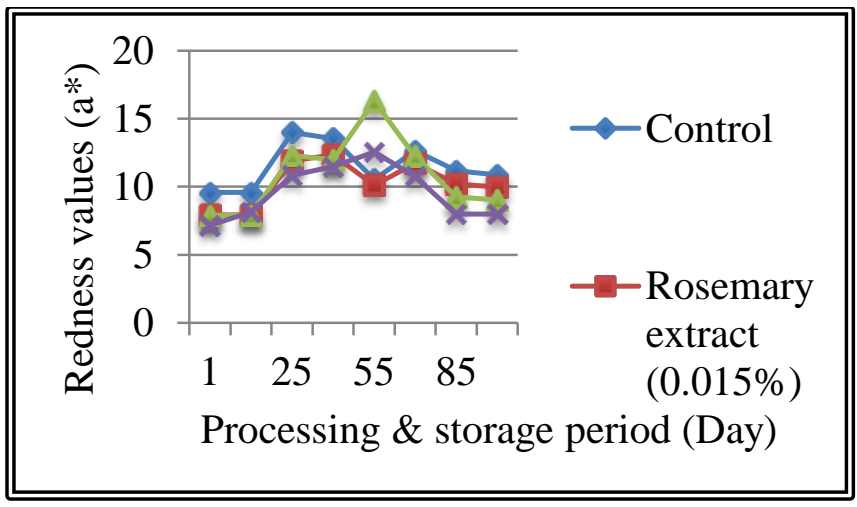

Fig. (6). Mean redness values $\left(a^{*}\right)$ for dry fermented lamb-meat sausage samples during processing and storage period.

Redness values, $a^{*}$, for this study are in agreement with those that found by other authors for modified fermented sausages [27-29]. McCarthy and others [30] observed that inclusion of rosemary significantly increased the $\mathrm{a}^{*}$ on meat patties by the $9^{\text {th }}$ day of storage. A study by Martinez and others [31] had similar results regarding the use of a mixture of rosemary and ascorbic acid in sausages.

Yellow color, $\mathrm{b}^{*}$, data, Fig. (7), showed that adding rosemary extract to the sausages decreased the value of $b^{*}$ $(\mathrm{p}<0.05)$ with no statistically significant differences $(\mathrm{p}>$ 0.05 ) between all samples at day 1 . Mean values of $b^{*}$ in the final product (after day 100) were close for all samples (5.70, $6.31,5.35$ and 5.52), also, all treatments resulted in significantly lower $(\mathrm{p}<0.05)$ mean yellowness values $b^{*}$ than day 1 . Values for the yellowness parameter are in agreement with those found by other authors for salami and Spanish dry fermented sausages [28, 32].

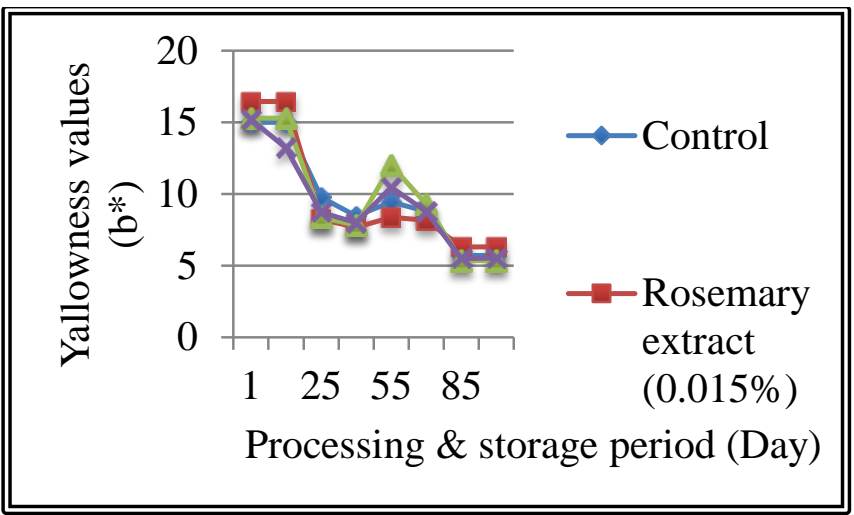

Fig. (7). Mean yellowness values $\left(b^{*}\right)$ for dry fermented lamb-meat sausage samples during processing and storage period.

Lightness, $\mathrm{L}^{*}$, values of the dry fermented lamb-meat sausages tended to decrease significantly over time $(\mathrm{p}<0.05)$, as seen in Fig. (8). Rosemary extract content and the drying process affected lightness values. Treatments with rosemary extracts gave the highest $L^{*}$ values (mean value $=48.56$, 45.97 and 46.97$)$ at day $1, L^{*}$ mean values were significantly different than the control (44.40) ( $\mathrm{p}<0.05)$. A similar trend was reported for dry fermented sausages [33] [11]. Also, Hernandez and others [34] reported that treatment with an ethanol rosemary extract resulted in lower $\mathrm{L}^{*}$ values (darker samples) on raw meat. In a study by Petrovic [35] on traditional sausages, lightness values decreased and sausages became darker during the drying and ripening (120 days) period. Ordonez and others [36] reported, "If the fat content increases, the lightness of meat product also increases" in conventional and low-fat frankfurter. This was not observed in the current study, even with a fat content of about $30 \%$.

Results for the Chroma parameter, $\mathrm{C}^{*}$, in Fig. (9) show a significant $(\mathrm{p}<0.05)$ decreasing trend with time. The Chroma mean values at day 1 were $17.84,18.26,17.22$ and 
16.80. At the end of the storage period, the Chroma mean values were $12.22,11.88,10.36$ and 9.51 respectively for control and rosemary extract added sausage samples.

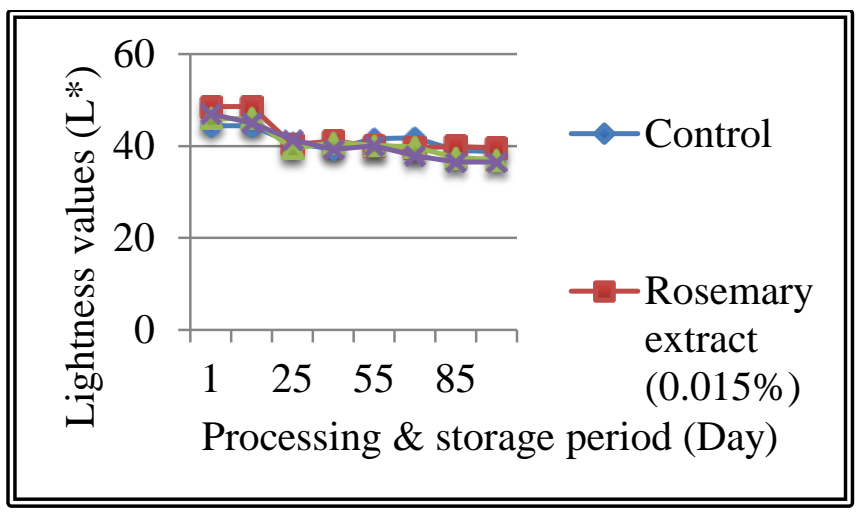

Fig. (8). Mean lightness values $\left(L^{*}\right)$ for dry fermented lamb-meat sausage samples during processing and storage period.

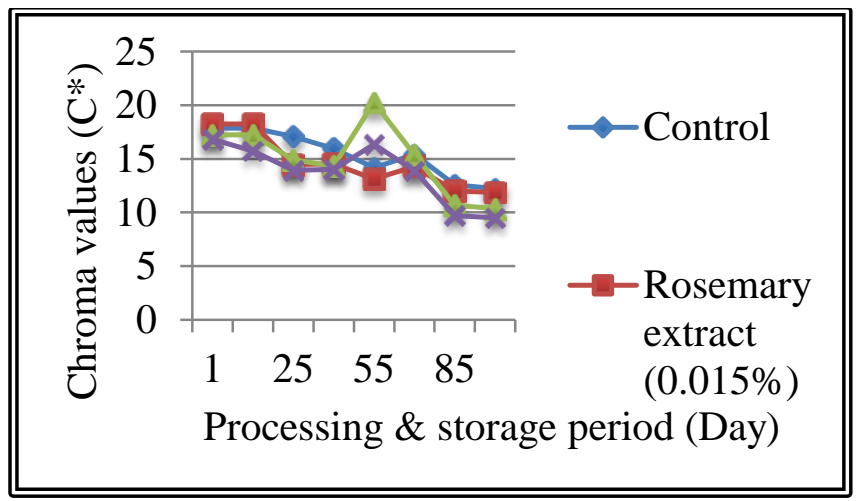

Fig. (9). Mean Chroma values $(C *)$ for dry fermented lamb-meat sausage samples during processing and storage period.

Sanchez and others [37] reported that myoglobin and oxymyoglobin oxidation lead to formation of brown metmyoglobin, which is associated with a reduction in reddish color (lower Chroma). In the current study, brown metmyoglobin didn't occur even though Chroma values decreased through the processing and storage time. The rosemary extract may have protected the sausage color by reducing oxidation. The results of the current study were in agreement with Hernandez-Hernandez and others [34] who reported that the red color of meat pigments when oxidized were associated with decreased Chroma values.

Hue, $h^{*}$, refers to the characteristic of any chromatic color that distinguishes it from other hues found between the ends of the spectrum, red, yellow, green, blue or purple (principal hues). Mean $\mathrm{h}^{*}$ values, shown in Fig. (10), have a decreasing trend $(\mathrm{p}<0.05)$. At day 1 the antioxidant samples showed a highest mean values $(64.25,62.68$ and 64.01 respectively) when compared with the control samples (57.64). Results were similar at day 100. These results showed that when the percentage of rosemary extract was increased, mean $h^{*}$ values were reduced. Hue showed a decreasing trend in samples, which became darker with time. Low mean values (more reddish samples) were observed for sausages with added rosemary extract. Decreasing $\mathrm{h} *$ values were in agreement with Chizzolini and others [38] in a study of traditional Mediterranean meat products.

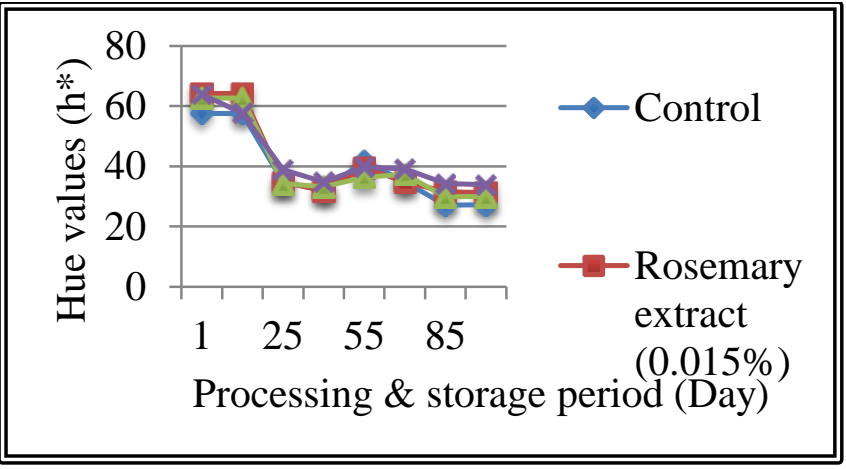

Fig. (10). Mean hue values $\left(h^{*}\right)$ for dry fermented lamb-meat sausage samples during processing and storage period.

Fourteen replicates for each treatment were analyzed for their sensory characteristics. Sensory attributes of appearance, juiciness, hardness and saltiness were not significantly different $(\mathrm{p}>0.05)$ in final products, while the sourness (acidity), color and off-odor values were significantly different $(\mathrm{p}<0.05)$ in samples.

Mean acidity (sourness) scores of the dry fermented lamb-meat sausages are given in Fig. (11). The origin of the sourness relates to the fermentation process and how the $\mathrm{pH}$ is reduced in all sausage samples from the processing through the ripening period. Sensory evaluation for sample acidity revealed that the samples with added rosemary extract $(0.030 \%)$ averaged higher scores than the control and the other rosemary extract treatments $(\mathrm{p}<0.05)$, followed by sausage samples with the $0.045 \%$ rosemary extract treatment. The mean scores of sourness in the final products were $4.57,4.78,6.07$ and 5.64 on a 10-point scale $(1=$ imperceptible to $10=$ extremely) for the control and rosemary extract $(0.015,0.030$ and $0.045 \%)$ sausage samples respectively.

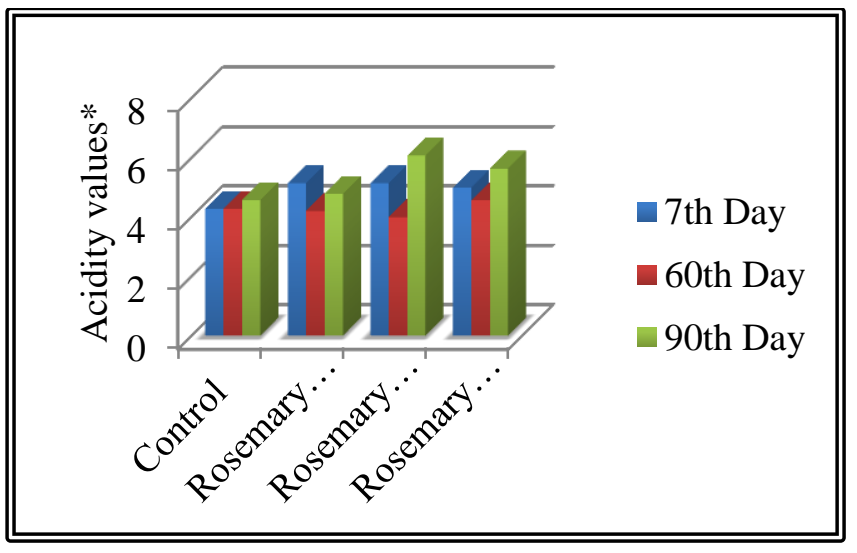

*Acidity evaluation scale (10-points): $1=$ imperceptible $/ 10=$ extremely.

Fig. (11). Mean acidity values for dry fermented lamb-meat sausage samples during processing and storage period.

With respect to specific characteristics that indicate product oxidation, some comments like "soap flavor" and "rancid" were observed by panelists for the control and $0.015 \%$ (lower antioxidant level) rosemary treatments. Mendoza and others [21] observed that the acidity value increased quickly during the first few days of the ripening 
period in dry fermented sausages depending on the $\mathrm{pH}$ value. Also Balev and others [39] reported similar results for dry fermented sausage.

Results of a sensory evaluation of dry fermented lambmeat sausage color values are presented in Fig. (12). Significant differences $(\mathrm{p}<0.05)$ in redness values were found between product samples at day 7 . Results showed that the dark red color increased with increasing amounts of rosemary extract. Ruiz and others [40] reported that dryfermented sausages had significant differences between redness values assessed by sensory panelists. Also, similar results reported by Bovolenta and others [41] when they evaluated the sensory properties of fermented Alpagota sheep sausage.

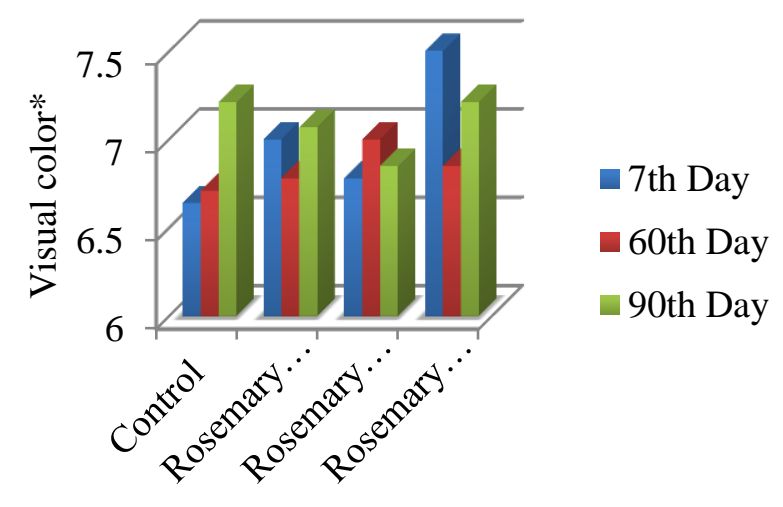

*Visual color (redness) evaluation scale (10-points): 1 = extremely light $/ 10=$ extremely dark.

Fig. (12). Mean visual color values for dry fermented lamb-meat sausage samples during processing and storage period.

Addition of antioxidants was not effective in protecting sausages from changes in external appearance. Mean values of the appearance scores of the dry fermented lamb-meat sausage samples are shown in Fig. (13). There was no significant difference ( $p>0.05$ ) between sample appearances. Most samples were conventional in appearance with some contraction in the external surface. Wrinkles on the surface of the sausages were caused by the ripening/drying process and storage time. The addition of rosemary extract had no effect ( $p>0.05)$ on the appearance of the surface or cross section of all sausage samples. These results were in agreement with Liaros and others [42] and Olivares and others [3].

Off-odor profiles are shown in Fig. (14). Samples with rosemary extract added showed no significant differences ( $p>0.05$ ) between off-odors. Off-odor scores for the control samples increased $(\mathrm{p}<0.05)$ throughout processing and storage periods. At day 90, the off-odor means values were 4.85 for control sausage samples and, $4.28,4.08$ and 3.93 for rosemary extract $(0.015,0.030$ and $0.045 \%)$ sausage samples, respectively. The antioxidant capacity of rosemary extract was able to protect sausages from off-odor formation. Similar results were reported by Kamenik and others [25] Ordonez and others [2], and Vittorio and others [43].

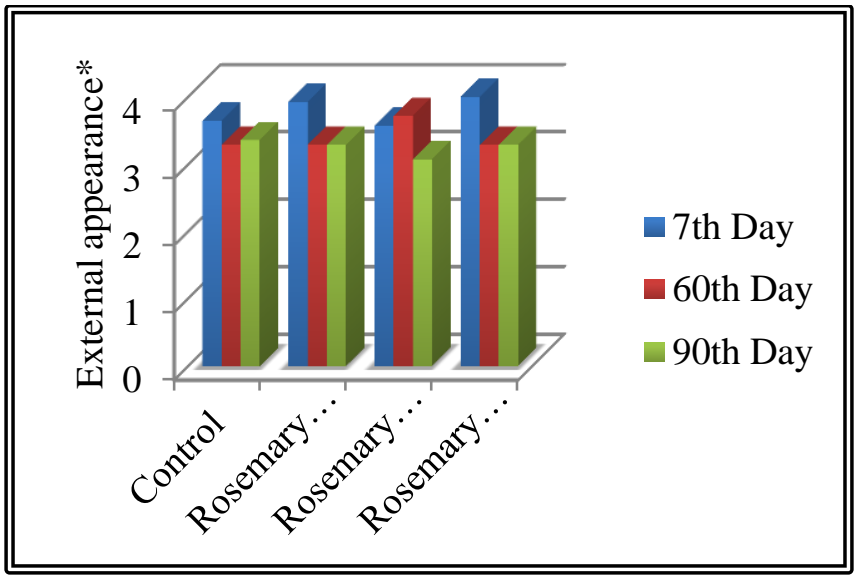

*External appearance evaluation scale (10-points): $1=$ conventional appearance to $10=$ unexpected appearance.

Fig. (13). Mean external appearance values for dry fermented lambmeat sausage samples during processing and storage period.

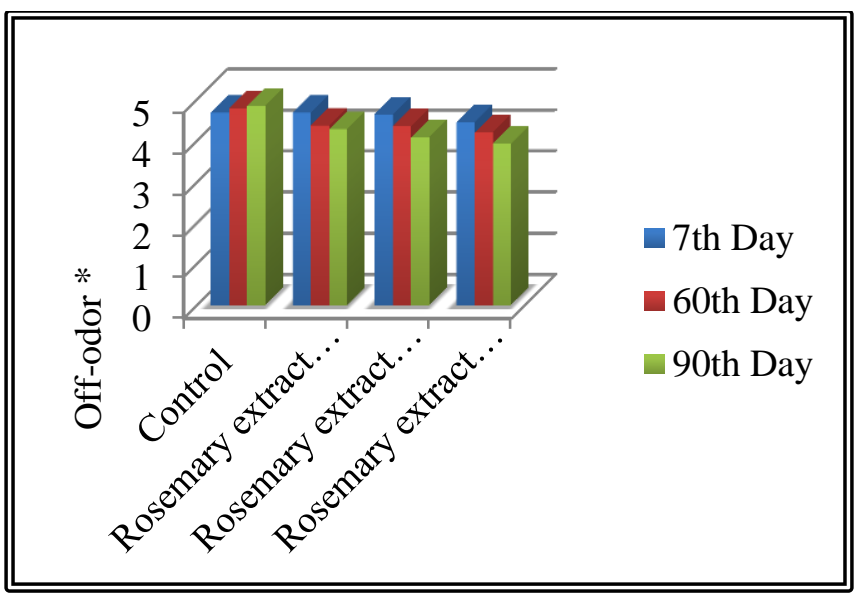

* Off-odor evaluation scale (10-points): $1=$ imperceptible $/ 10=$ extremely intense.

Fig. (14). Mean off-odor profile values for dry fermented lambmeat sausage samples during processing and storage period.

Fig. (15) represents the mean hardness values of dry fermented lamb-meat sausage samples. No significant difference $(\mathrm{p}>0.05)$ between samples was observed during the ripening and drying periods. High fat content in sausage samples generally results in lower hardness values, as evidenced in previous sensory analyses performed on dry fermented sausages [24, 35, 41]. Previous studies were unable to elucidate how these changes affect consumer acceptability to establish an optimum fat content.

Mean juiciness scores obtained for the control and test batches are shown in Fig. (16). No significant difference (p> 0.05 ) of juiciness between rosemary extract treatments was observed. Juiciness was slightly better in sausage samples with rosemary extract, probably due to the physical properties and palatability of the fat content. In a study by Helgesen and Naes [44] results indicated that fat content and juiciness were weakly correlated in dry fermented lamb sausage, furthermore, sausages with the highest intensity of juiciness were all high in water content and had a high water activity. This did not occur in this study. Similar results were reported by Liu and others [45] for various levels of 
rosemary or Chinese mahogany in chicken sausage. Manuel and others [46] reported high juiciness scores for bologna sausage with added rosemary essential oil.

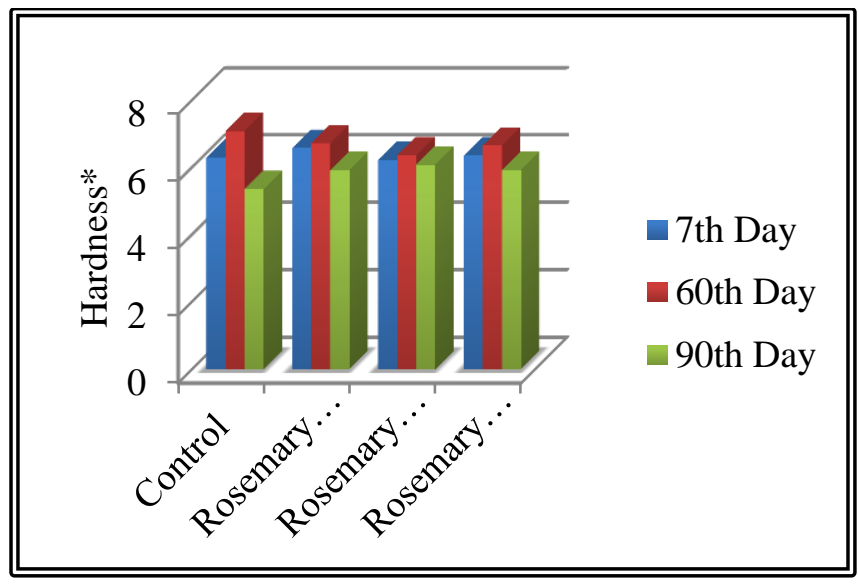

* Hardness evaluation scale (10-points): $1=$ extremely soft to $10=$ extremely intense.

Fig. (15). Mean hardness profile values for dry fermented lambmeat sausage samples during processing and storage period.

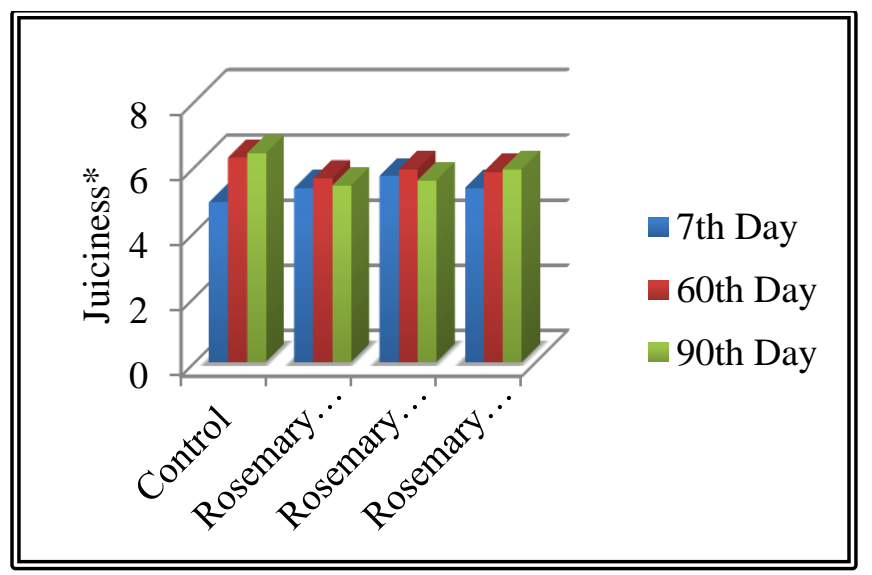

* Juiciness evaluation scale (10-points): $1=$ extremely dry to $10=$ extremely moist.

Fig. (16). Mean juiciness profile values for dry fermented lambmeat sausage samples during processing and storage period.

Salt is an important factor that influences the flavor of fermented sausages. Saltiness scores for dry fermented lambmeat sausage are shown in Fig. (17). No significant difference $(p>0.05)$ of salty taste between treatments was observed. The results of the current study revealed a reduction in mean saltiness scores during the ripening and storage times for all samples except the control. As the salt concentration increased, sausages tended to become drier and harder, but this did not occur in the current study.

Bovolenta and others [41] reported that fat content increased the perception of the salty taste, and this could explain the comparable intensity of salty taste perception in low fat (and higher salt content) and high fat (and lower salt content) fermented sheep products. However, saltiness values for the current study might be related to the fat content of the final products. In addition, moisture content, drying methods and storage time may affect the salty taste.

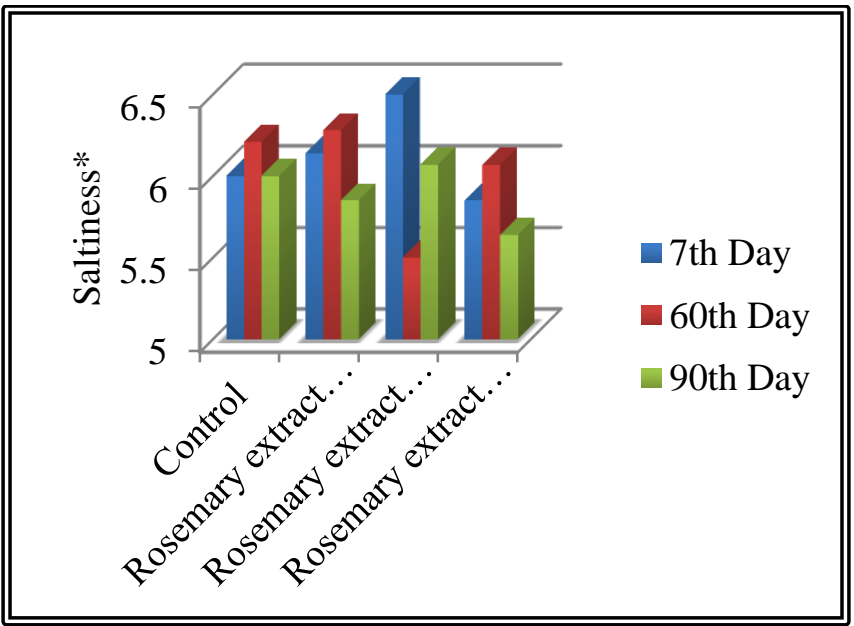

* Saltiness evaluation scale (10-points): $1=$ imperceptible to $10=$ extremely.

Fig. (17). Mean saltiness profile values for dry fermented lambmeat sausage samples during processing and storage period.

\section{DISCUSSION}

The main aim of present study was to develop and evaluate a dry fermented lamb-meat sausage manufactured with different rosemary extract concentrations using controlled ripening/drying conditions and fermented process. We have shown that rosemary extract, as applied in this study, improves fermented lamb-meat sausage quality based on color and off-odor. Natural rosemary extract is an effective alternative to synthetic antioxidants for extending shelf life of dry fermented lamb-meat sausage.

Moisture content, protein concentration, $\mathrm{pH}$, and $\mathrm{a}_{\mathrm{w}}$ of sausage samples decreased during storage, while protein, ash, and fat increased. Results of moisture, $\mathrm{pH}$, water activity and moisture/protein ratio (MPR) satisfied the labeling standards of the FSIS for shelf stable products.

Color analysis indicated that the red component, $a^{*}$, increased significantly due to the incorporation of nitrite, nitrate addition and the fermentation process. Samples containing rosemary extract $(0.045 \%)$ had the lowest mean $\mathrm{a}^{*}$ values at the end of the storage period. Mean yellowness, $b^{*}$, values were significantly lower for samples containing rosemary extract $(0.030 \%)$ at the end of storage. Chroma, $\mathrm{C}^{*}$, and color hue, $\mathrm{h}^{*}$, mean values decreased for all samples in storage. The addition of rosemary extract as natural antioxidant provided significant protection of color parameters for dry fermented lamb-meat sausages.

Sensory evaluation indicated that the characteristics of juiciness, hardness and saltiness were not significantly different in final products, while the sourness (acidity), color and off-odor values were significantly different for samples. Sensory evaluation revealed that acidity values increased quickly during the first few days of the ripening period. Panelists also perceived that samples with rosemary extract had higher redness in agreement with measurements of the $\mathrm{a}^{*}$ index. External appearance scores for all samples were lower on day 90 compared to day 7. Off-odor scores were lower for all samples treated with rosemary compared to the control. 


\section{CONFLICT OF INTEREST}

The authors confirm that this article content has no conflict of interest.

\section{ACKNOWLEDGEMENTS}

The authors acknowledge the Robert M. Kerr Food \& Agricultural Products Center at the Oklahoma State University, Stillwater, for providing the facilities, equipment, and funding for this work.

\section{REFERENCES}

[1] Ordonez JA, Hierro EM, Bruna JM, Hoz LD. Changes in the components of dry-fermented sausages during ripening. Cr Rev Food Sci Nutr 1999; 39 (4): 329-67.

[2] Leroy F, Verluyten J, Vuyst LD. Functional meat starter cultures for improved sausage fermentation. Inter J Food Micro 2006; 106: 270-85.

[3] Olivares A, Navarro JL, Salvador A, Flores M. Sensory acceptability of slow fermented sausages based on fat content and ripening time. Meat Sci 2010; 86: 251-7.

[4] Marco A, Navarro JL, Flores M. The sensory quality of dry fermented sausages as affected by fermentation stage and curing agents. Eur. Food Res Technol 2008; 226: 449-58.

[5] McBride NT, Hogan SA, Kerry JP. Comparative addition of rosemary extract and additives on sensory and antioxidant properties of retail packaged beef. Inter J Food Sci Technol 2007; 42: 1201-7.

[6] Waszkowiak K, Dolata W. The application of collagen preparations as carriers of rosemary extract in the production of processed meat. Meat Sci 2007; 75: 178-83.

[7] Kong B, Zhang H, Xiong YL. Antioxidant activity of spice extracts in a liposome system and in cooked pork patties and the possible mode of action. Meat Sci 2010; 85: 772-8.

[8] Nunez-Gonzalez MT, Boleman RM, Miller RK, Keeton JT, Rhee KS. Antioxidant properties of dried plum ingredients in raw and precooked pork sausage. J Food Sci 2008; 73(5): H63-71

[9] Sherwin ER. Antioxidants. In Food Additives, 1st Ed. (A.L. Branen, P.M. Davidson and S. Salminen, eds.), Marcel Dekker, Inc., New York, NY. 1990; 139-191. Available from: http://www.fsis.usda.gov/oppde/rdad/fsisdirectives/5100.2/meatand _poultry_hazards_controls_guide_10042005.

[10] Tsen SY, Ameri F, Smith JS. Effects of rosemary extracts on the reduction of heterocyclic amines in beef patties. J Food Sci 2006; 71 (8): 469-73.

[11] Fernandez-Lopez J, Zhi N, Aleson-Carbonell L, Perez-Alvarez JA, Kuri V. Antioxidant and antibacterial activities of natural extracts: Application in beef meatballs. Meat Sci 2005; 69: 371-80.

[12] Formanek Z, Lynch A, Galvin K, Farkas J, Kerry JP. Combined effects of irradiation and the use of natural antioxidants on the shelf life stability of overwrapped minced beef. Meat Sci 2003; 63(4): 433-40

[13] Georgantelis D, Blekas G, Katikou P, Ambrosiadis L, Fletouris DJ. Effect of rosemary extract, chitosan and $\propto$-tocopherol on lipid oxidation and color stability during frozen storage of beef burgers. Meat Sci 2007; 75: 256-64.

[14] AOAC. Methods of Analysis of Association of Official Agricultural Chemists. $17^{\text {th }}$ Ed. Associatio of Official Analytical Chemists, Washington, DC. 1997: 684-97.

[15] Djenane-Sanchez-Escalante A, Djenane D, Torrescano G, Beltran JA, Roncales, P. The effects of ascorbic acid, taurine, carnosine and rosemary powder on color and lipid stability of beef patties packaged in modified atmosphere. Meat Sci 2001; 58: 421-49.

[16] Martınez, L, Cilla I, Beltran JA, Roncales P.. Combined effect of modified atmosphere packaging and addition of rosemary (Rosmarinus officinalis), ascorbic acid, red beet root (Beta vulgaris), and sodium lactate and their mixtures on the stability of fresh pork sausages. J Agri Food Chem 2006b; 54: 4674-80.

[17] Vuorel S, Salminen H, Makela M, Kivikar R,Karonen M, Heinonen M. Effect of plant phenolic on protein and lipid oxidation in cooked pork meat patties. J Agric Food Chem 2005; 53: 8492-7.
[18] Kjaersgard IV, Jessen F. Two-dimensional gel electrophoresis detection of protein oxidation in fresh and tainted rainbow trout muscle. J Agric Food Chem 2004; 52: 7101-7.

[19] Coffey A, Ryan M, Ross RP, Hill C, Arendt E, Schwarz G. Use of a broad-host-range bacitracin-producing Lactococcus lactis transconjugant as an alternative starter for salami manufacture. Intl J Food Microbiol 1998; 43(3): 231-5.

[20] FSIS Food Safety and Inspection Service. Performance standards of the production of certain meat and poultry products. Federal Register 1999; 64(3): 732-49.

[21] Mendoza E, Garcia ML, Casas C, Selgas MD. Inulin as fat substitute in low fat, dry fermented sausages. Meat Sci 2001; 57: 387-93.

[22] Garcia ML, Dominguez R, Galvez MD, Casas C, Selgas MD. Utilization of cereal and fruit fibers in low fat dry fermented sausages. Meat Sci 2002; 60: 227-36.

[23] USDA U.S. Department of Agriculture, FSIS Food Safety and Inspection Service. Meat and poultry hazards and controls guide 2005; Available from: http://www.fsis.usda.gov/oppde/rdad/fsisdire ctives/5100.2/meatand_poultry_hazards_controls_guide_10042005.

[24] Papadima SN, Bloukas JG. Effect of fat level and storage conditions on quality characteristics of traditional Greek sausages Meat Sci 1999; 51: 103-13.

[25] Kamenik J, Salakova A, Borilova G, Pavlik Z, Standarova E, Steinhauser L. Effect of storage temperature on the quality of dry fermented sausage Poličan. Czech J Food Sci 2012; 30(4): 293301.

[26] Zanardi E, Novelli E, Ghiretti GP, Dorigoni V, Chizzolini R. Color stability and vitamin $\mathrm{E}$ content of fresh and processed pork. Food Chem 1999; 67: 163-71

[27] Bloukas JG, Paneras ED, Fournitzis GC. Effect of replacing pork back fat with olive oil on processing and quality characteristics of fermented sausages. Meat Sci 1997; 45: 133-44.

[28] Severini C, De Pilli T, Baiano A. Partial substitution of pork back fat with extra-virgin olive oil in "salami" products: Effects on chemical, physical and sensory quality. Meat Sci 2003; 64: 323-31.

[29] Hoz L, D'Arrigo M, Cambero I, Ordonez JA. 2004. Development of an n-3 fatty acid and $\propto$-tocopherol enriched dry fermented sausage. Meat Sci 2004: 67: 485-95.

[30] Mccarthy TL, Kerry JP, Kerry JF, Lynch PB, Buckley DJ. Evaluation of the antioxidant potential of natural food/plant extracts as compared with synthetic antioxidants and vitamin $\mathrm{E}$ in raw and cooked pork patties. Meat Sci 2001; 57: 45-52.

[31] Martınez, L, Cilla I, Beltran JA, Roncales P. Antioxidant effect of rosemary, borage, green tea, pu-erh tea and ascorbic acid on fresh pork sausages packaged in modified atmosphere. Influence of the presence of sodium chloride. J Sci Food Agri 2006a; 86: 1298-307.

[32] Fernandez-Lopez J, Sendra E, Sayas-Barbera ME, Navarro C, Perez-Alvarez JA. Physico-chemical and microbiological profiles of "Salchichón" (Spanish dry-fermented sausage) enriched with orange fiber. Meat Sci 2008; 80: 410-7.

[33] Caceres E, Garcia ML, Toro J, Selgas MD. The effect of fructooligosaccharides on the sensory characteristics of cooked sausages. Meat Sci 2004; 68(1): 87-96.

[34] Hernandez-Hernandez E, Ponce-Alquicira E, Jaramillo-Flores ME, Guerrero Legarreta I. Antioxidant effect of rosemary (Rosmarinus officinalis L.) and oregano(Origanum vulgare L.) extracts on TBARS and color of model raw pork batters. Meat Sci 2009; 81(2): 410-7.

[35] Petrovic L, Dzinic N, Ikonic P, Tasic T, Tomovic V. Quality and safety standardization of traditional fermented sausages. Technol. Mesa 2011; 52(2): 234-44

[36] Ordonez M, Rovira J, Jaime I. The relationship between the composition and texture of conventional and low-fat frankfurter. Inter J Food Sci Technol 2001; 36: 749-58.

[37] Sanchez-Escalante A, Djenane D, Torrescano G, Beltran, JA, Roncales P. Antioxidant action of borage, rosemary, oregano, and ascorbic acid in beef patties packaged in modified atmosphere. $\mathbf{J}$ Food Sci 2003; 68: 339-4.

[38] Chizzolini R, Novelli E, Zanardi E. Oxidation in traditional Mediterranean meat products. Meat Sci 1998; 49: S87-99.

[39] Balev D, Vulkova T, Dragoev S, Zlatanov M, Bahtchevanska S. A comparative study on the effect of some antioxidants on the lipid and pigment oxidation in dry-fermented sausages. Int. J Food Sci Technol 2005; 40: 977-83. 
[40] Ruiz PC, Galan-Soldevilla H, Leon C, Molina R. Determination of the sensory attributes of a Spanish dry-cured sausage. Meat Sci 2005; 71: 620-33.

[41] Bovolenta S, Boscolo D, Dovier S, Morgante M, Pallotti A, Piasentier E. Effect of pork lard content on the chemical, microbiological and sensory properties of a typical fermented meat product (Pitina) obtained from Alpagota sheep. Meat Sci 2008; 80: 771-9.

[42] Liaros NG, Katsanidis E, Loukas JG. Effect of the ripening time under vacuum and packaging film permeability on processing and quality characteristics of low fat fermented sausages. Meat Sci 2009; 83: 589-98.

[43] Vittorio MM, Giuseppe M, Carlo D, Tiziana M, Maria AP, Sara P, Giuseppe P, Gustavo G. Chemical and microbiological parameters and sensory attributes of a typical Sicilian salami ripened in different conditions. Meat Sci 2004; 66: 845-54.

[44] Helgesen H, Naes T. 1995. Selection of dry fermented lamb sausages for consumer testing. Food Quality and Preferance, 6: 109-20.

[45] Liu DC, Tsau RT, Lin YC, Jan SS, Tan FJ. Effect of various levels of rosemary or Chinese mahogany on the quality of fresh chicken sausage during refrigerated storage. Food Chem 2009; 117:106-13.

[46] Manuel VM, Yolanda RN, Juana FL, Jose AP. Effect of adding citrus fiber washing water and rosemary essential oil on the quality characteristics of a bologna sausage. LWT- Food Sci \& Techno 2010; 43: 958-63.

(C) Bowser et al.; Licensee Bentham Open.

This is an open access article licensed under the terms of the Creative Commons Attribution Non-Commercial License (http://creativecommons.org/licenses/ by-nc/3.0/) which permits unrestricted, non-commercial use, distribution and reproduction in any medium, provided the work is properly cited. 